\title{
The Role of Policy Rules in Inflation Targeting
}

\author{
Kenneth N. Kuttner
}

No rule is so general, which admits not some exception.

-Robert Burton, Anatomy of Melancholy

\section{INTRODUCTION}

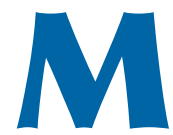

ore than 13 years have elapsed since the

Reserve Bank of New Zealand's pioneering introduction of a formal inflation target in 1990, a framework subsequently adopted by at least 21 other central banks. Collectively, these 22 countries represent more than 132 country-years of experience with inflation targeting (IT). ${ }^{1}$ This accumulation of experience has led to a growing understanding of the practical and institutional features of the policy; see, for example, Bernanke et al. (1999), Sterne (2002), Mishkin and SchmidtHebbel (2002), and Truman (2003). Roughly in parallel with central banks' embrace of IT, there has been an explosion of research on monetary policy rules - spawned in no small part by Taylor's (1993) influential paper. This line of research has blossomed in recent years, especially with the theoretical contributions of Clarida, Galí, and Gertler (1999), Svensson (2003), Woodford (2003), and Giannoni and Woodford (2003a,b) on optimal policy rules, to name just a few.

Given these parallel developments in central banking practice and monetary theory, it is no surprise that a great deal of recent research has modeled IT as some sort of a monetary policy rule. Views differ on the usefulness of describing IT in these terms, however. Coming at the question from a practical

\footnotetext{
1 An annotated listing of inflation targeters can be found in Mishkin and Schmidt-Hebbel (2002). A similar list of inflation targeters appears in Truman (2003) and in each volume of the International Monetary Fund's International Financial Statistics.
}

standpoint, Bernanke et al. (1999) describe IT as a "framework" rather than as a rule. In a similar vein, Gavin (2004), characterizes IT as "management by objective," rather than as a well-defined policy rule. On the other end of the spectrum, Svensson (1999) defines IT as a monetary policy rule derived from an explicit optimization problem. Much of the difficulty in defining IT is due to its humble origins in central banking practice, and policymakers' pragmatic search for a suitable nominal anchor. Svensson's definition can therefore be seen as part of a broader effort to retrofit macroeconomic theory to a policy that was developed largely in the absence of a formal theoretical framework. ${ }^{2}$

Clearly, neither polar view can adequately characterize IT as it is actually practiced. For IT as a "framework" or a "management objective" to make any difference to macroeconomic outcomes, it must translate into some sort of change in central bank behavior. And this change, in turn, should have implications for the empirical policy rule used to describe policymakers' behavior. Similarly, surely no central bank sees itself as an automaton mechanically implementing a policy rule. The goal of this paper is therefore to determine where central banking practice lies on the "guidelines versus rules" spectrum and, specifically, to assess empirically the extent to which IT can be described in terms of simple monetary policy rules.

The task of characterizing IT in terms of a policy rule is complicated both by conflicting definitions of the term "policy rule" and by differing interpretations of what IT entails in practice, however. In an attempt to clarify what is meant by the term, section 2

\footnotetext{
2 As Goldfeld (1984) quipped in a different context, "An economist is someone who sees something working in practice and asks whether it would work in principle."
} 
reviews the various definitions of "policy rule." Section 3 describes how IT is implemented and how this practice might be mapped into the sorts of rules summarized in the preceding section. Section 4 then characterizes the behavior of major IT central banks econometrically, with the various interpretations of "policy rule" as a guide. The novel feature of our empirical analysis is the use of central banks' own inflation and output forecasts, exploiting the overlapping nature of these forecasts in order to estimate the response of policy to new information. Section 5 concludes.

\section{POLICY RULES: A GUIDE FOR THE PERPLEXED}

The explosion in research on monetary policy rules has resulted in a proliferation of definitions of the term "policy rule." This has, not surprisingly, led to some confusion in the literature, and discussions of the topic often flounder on issues of terminology. Naturally, the answer to the question of whether IT can be described by a policy rule will depend a great deal on what exactly is meant by the term. ${ }^{3}$ This section provides a brief review of some of the alternative definitions in an effort to clarify some of these issues.

\section{Conditional Versus Unconditional Rules}

The easiest rules to enforce, of course, are simple ones. And in the context of monetary policy rules, the simplest sort of rule would be something like the fixed money supply rule analyzed in Rogoff (1985) and King (1997). Such a "non-contingent" or unconditional rule represents an inflexible commitment to a nominal anchor and obviously prohibits any sort of response to economic conditions. In certain models, this kind of inflexibility can result from assigning a zero weight to output fluctuations in the central bank's loss function, a case King (1997) refers to as that of the "inflation nutter." Such a rule would, by construction, not allow the central bank to (optimally) offset the effects of supply shocks on output. And as pointed out by Rogoff (1985), such a rule would also prevent the central bank from accommodating nominal money demand shocks, potentially introducing more volatility in output and inflation. It is this sort of inflexible rule that was criticized by Friedman and Kuttner (1996), among others. Recent

\footnotetext{
3 Bofinger (2000) also grapples with the problem of mapping IT into
} alternative definitions of a policy rule. research has deemphasized these unconditional policy rules, however, and the focus now is much more on the design of flexible, conditional rules that allow the policymaker to respond in a reasonable (or even optimal) manner to economic conditions.

\section{Ad Hoc Versus Optimal Rules}

Among those "state contingent" rules that allow policy to respond to economic conditions, a broad distinction can be drawn between ad hoc policy rules relating the policy instrument to some selection of macroeconomic variables and those rules derived from an explicit optimization problem. Taylor's (1993) eponymous rule

$$
i_{t}=r^{*}+\pi^{*}+0.5 x_{t}+1.5\left(\pi_{t}-\pi^{*}\right)
$$

is of course the best-known example of the former; here, $i_{t}$ is the nominal policy interest rate, $r^{*}$ is the equilibrium real rate of interest, $\pi^{*}$ is the desired or "target" level of inflation, $\pi_{t}$ is the current rate of inflation, and $x_{t}$ is the output gap. ${ }^{4}$ Another example is the inflation forecast-based (IFB) rule proposed by Batini and Haldane (1999), in which the nominal interest rate depends on a distributed lead of $\tau$-period-ahead inflation forecasts made at time $t, \pi_{t+\tau, t}$ (ignoring interest rate smoothing for simplicity):

$$
i_{t}=r^{*}+\pi^{*}+\sum_{\tau} \theta_{\tau} \pi_{t+\tau, t} .
$$

By contrast, rules based on an explicit optimization problem are almost invariably based on setting policy in such a way as to minimize a loss function of the form

$$
E_{t} \sum_{\tau=0}^{\infty} \delta^{\tau}\left[\left(\pi_{t+\tau}-\pi^{*}\right)^{2}+\lambda x_{t+\tau}^{2}\right] .
$$

The optimal response of the interest rate derived from (3) will in general not be given by (1) or (2), although it is often possible to reverse-engineer objective functions that would rationalize such rules. Nonetheless, these sorts of rules tend to produce reasonable (if not optimal) policy responses, provided the sum of the inflation coefficients exceeds unity, thus satisfying the Taylor principle. This observation has led to a vast literature comparing the performance of simple ad hoc rules, like Taylor's, with the optimal policy response for a variety of models. See,

\footnotetext{
4 To make the rule operational, Taylor used the current year-over-year inflation rate for $\pi_{t}$ and linearly detrended output for $x_{t}$.
} 
for example, Rudebusch and Svensson (1999) and Williams (2003).

\section{Targeting Versus Instrument Rules}

Probably the most familiar way to characterize the conduct of monetary policy is in terms of an instrument rule involving the policy instrument itself. Equations (1) and (2) are examples in which the nominal interest rate is the policy instrument. Although these examples are ad hoc rules, it would also be possible to insert the relevant structural relationships into the first-order condition from minimizing (3) to yield the optimal instrument rule for a particular model. A distinction is also sometimes made between explicit instrument rules involving predetermined macro variables (i.e., ones that do not depend on the current setting of the policy instrument) and implicit rules whose arguments are jointly determined with the policy instrument (as would typically be the case if the rule's arguments included forecasts). An explicit rule can be interpreted as a simple "recipe" for policy, while implementing an implicit rule (such as the IFB) requires that the policymaker account for the feedback between the instrument and the arguments of the rule.

A less familiar way to characterize policy is directly in terms of the targeted variables themselves, yielding what is referred to as a targeting rule. An optimal targeting rule could either take the form of simply pledging to minimize (3) (a "general" targeting rule in Svensson's terminology) or setting policy in such a way as to satisfy the first-order conditions from (3) describing the marginal trade-off facing the policymaker between output and inflation stabilization (a "specific" targeting rule). With a quadratic objective function, the first-order conditions imply a linear marginal trade-off between inflation and the output gap, such as those discussed in section 4. There are also ad hoc targeting rules involving only the central bank's goal variables, but which are not explicitly derived from an optimization problem. A prescription to achieve the desired inflation rate at a fixed horizon could be classified as a targeting rule of this type.

Because instrument rules can be derived from targeting rules (and vice versa), the distinction between the two is at some level artificial. The distinction is further blurred when a term involving the change in the interest rate is included in the objective function, presumably reflecting a preference for interest rate smoothing as in Giannoni and Woodford (2003a,b). In this case, the policy instru- ment would appear in the first-order condition, making the targeting rule indistinguishable from an implicit instrument rule.

Nonetheless, Svensson (2003) contends that formulating policy in terms of a targeting rule has several compelling advantages over an instrument rule. Chief among these is that targeting rules can more readily accommodate central bankers' "judgment" regarding special factors affecting inflation and output (macro models' ubiquitous "add factors"), as well as any unusual circumstances affecting the efficacy of the monetary transmission mechanism. Svensson shows that variables representing policymakers' judgment will typically enter the instrument rule formulation, rendering the implementation of policy by that route more complex and less intelligible. By contrast, these judgment variables do not appear in targeting rules. Intuitively, this is because the targeting rule embodies the central bank's imperative simply to do whatever it takes to achieve the appropriate balance between output and inflation stabilization, incorporating any judgment that might be appropriate in selecting the instrument setting needed to achieve the desired objective.

\section{Rules Describing Discretion Outcomes Versus Rules Derived from a Commitment}

Contributing to the terminological haze is the fact that the term "policy rule" has been used to describe both the outcome of discretionary policy setting (i.e., re-optimizing each period) and a condition that commits the central bank to potentially time-inconsistent actions in the future. In fact, as shown by Clarida, Galí, and Gertler (1999), a Taylorlike instrument rule can be derived as the optimal instrument rule for a central bank acting under discretion. This observation means it is difficult to discern in practice whether a central bank has acted in a purely discretionary fashion or tempered that discretion with some sort of commitment. Merely finding that monetary policy is well-described econometrically by a simple policy rule like Taylor's therefore does not necessarily imply any sort of commitment. This is not to say that optimal policy rules derived under discretion are the same as those derived under precommitment. Indeed, a generic feature of the latter is some degree of "history dependence"-i.e., for the policy response to depend not only on the current state of the economy, but the lagged state of the economy as well (typically, 
the lagged output gap). ${ }^{5}$ As a practical matter, however, it may be difficult to detect this sort of behavior, especially in the presence of an interest rate smoothing objective.

\section{Mechanical Rules Versus Rules as "Guidelines"}

Related to the discretion-versus-commitment dimension is the distinction between a rule that functions as a strict prescription for policy actions, versus one that serves as a looser "guideline" or "framework" for the conduct of monetary policy. This distinction has a long history. Simons (1936), for instance, interpreted a policy rule as completely precluding any intervention on the part of the "authorities." "Monetary rules," Simons wrote, "must be compatible with the reasonably smooth working of the system. Once established, however, they should work mechanically, with the chips falling where they may" (Simons, 1936, pp. 13-14). Clearly, it is this strict, mechanical interpretation that Bernanke et al. (1999) object to as a characterization of IT. 6

It is also apparent that this is not what Taylor had in mind when he proposed his rule. "Policy rules are frequently written down in the form of a 'mechanical-looking' algebraic formula... But this does not mean that the only way that monetary policy rules can be used is for the central bank to follow them mechanically," Taylor wrote. "On the contrary, most recent proposals for monetary policy rules assume that they would be used as guidelines for policymakers, recognizing the need for some discretion in using the rule" (Taylor, 2000, p. 209).

Svensson's interpretation of a rule appears to be closer to that of Simon's than to Taylor's. He finds Taylor's looser interpretation of a rule "not sufficiently specific to be operational" on the grounds that "there are no rules for when deviations from the instrument rule are appropriate," which, he argues, creates an "inherent lack of transparency" (Svensson, 2003, p. 445). But Svensson does allow discretion to enter through the arguments of the

\footnotetext{
5 Confusing matters still further: Considering only rules that depend on the current state of the economy, the optimal instrument rule under commitment is the same as that obtained under discretion with a smaller weight on output in the loss function $(\lambda)$. See Clarida, Gali, and Gertler (1999).

6 Even while arguing that a monetary rule should be mechanical, Simons (1936) recognized that an unconditional rule, such as a fixed supply of money, would probably be too inflexible.
}

policy rules: e.g., via judgmental adjustments to forecasts or the policymakers' assessment of the policy setting required to attain the optimal outcome.

\section{WHAT DOES INFLATION TARGETING HAVE TO DO WITH POLICY RULES?}

The goal of this section is to make a connection between the various definitions of a policy rule discussed above and IT as it is actually practiced. To that end, it first outlines three ways in which IT could be interpreted within the context of monetary macro models. Second, it summarizes the key features of IT as it is practice by self-described inflation targeters. The section concludes by highlighting dimensions along which the practice of IT does (or does not) map into the theoretical characterizations of IT.

\section{A Theoretical Taxonomy}

Perhaps the weakest definition of IT is having some desired rate of inflation, $\pi^{*}$, (which need not be announced) and employing a reaction function or instrument rule that satisfies the "Taylor principle" of a greater-than one-for-one response to expected inflation, thus ensuring that eventually inflation returns to $\pi^{*}$. The reaction function may of course also include a response to the output gap. This could be called "weak form" IT. The reaction function need not be optimal, in the sense of being derived from an explicit loss minimization problem. Under this definition, even following a simple ad hoc Taylorstyle rule will work. Gali (2002) and McCallum (2002), among others, define IT in this way.

A stronger definition of IT ("semi-strong form IT") restricts membership in the club to those central banks following an optimal monetary policy, i.e., setting policy in such a way as to minimize a relatively explicit loss function like (1) above. This is the definition in Svensson (1999). ${ }^{7}$ This optimization need not be carried out subject to any sort of precommitment, however. Indeed, the optimal instrument rule derived under the assumption of discretionary, period-by-period optimization in Clarida, Galí, and Gertler (1999) is described as a rule that characterizes IT.

The strongest conceptual definition of IT ("strong-form IT") is in terms of optimal monetary policy under conditions of precommitment (or alter-

\footnotetext{
7 Svensson's (1999) definition goes even farther, defining IT narrowly as an optimal targeting rule, although it is not clear why optimal policy could not also be implemented with an instrument rule.
} 
natively the "timeless" perspective). The optimal policy rule derived under these assumptions involves a commitment to a time-inconsistent course of future action on the part of the central bank: e.g., reducing inflation today by the promise to run negative output gaps in the future. ${ }^{8}$ Svensson (1999) seems to be agnostic as to whether IT necessarily involves such a precommitment, although he argues that IT can, at least, help reduce or eliminate any inflation bias resulting from an above-equilibrium output target. The precommitment solution is clearly what King (1997) had in mind in his description of IT, however, and this is also apparently the view of Giannoni and Woodford (2003c). ${ }^{9}$

\section{Inflation Targeting in Practice}

Although the practice of IT is anything but uniform across countries, a number of elements are common to most self-declared inflation targeters. These include ${ }^{10}$

- An emphasis on long-run price stability as the principal goal of monetary policy: This is not to say that price stability is the only goal, however - only that other objectives can be pursued only to the extent that they are compatible with the inflation target. ${ }^{11}$

- An explicit numerical target for inflation and a timetable for reaching that target: Most are in the neighborhood of 2 percent, and all aim to achieve the target at a horizon of no more than two years.

- A high degree of transparency with regard to monetary policy formulation: Most inflation targeters publish a detailed report on general economic conditions and the outlook for inflation in particular, typically at a quarterly frequency. In some cases, these reports include numerical projections of key macroeconomic variables.

- A mechanism for accountability: Besides promoting transparency, the central banks'

\footnotetext{
8 Or, in the case of Japan, increasing inflation today by the promise of running positive output gaps in the future, as in Eggertsson and Woodford (2003)

9 Oddly, the empirical application in Giannoni and Woodford (2003c) is to the Federal Reserve, which is generally not considered a fullfledged inflation targeter.

${ }^{10}$ A similar list of features is given in Truman (2003).

${ }^{11}$ Debelle (2003) points out that Australia is something of an exception in this regard, in that the Reserve Bank of Australia operates under a dual mandate of price stability and full employment.
}

published inflation reports also provide a means for ex post evaluation of inflation performance. Failure to fulfill the inflation target may require the central bank to take specific steps. For example, should inflation deviate by more than 1 percentage point from its 2.5 percent target, the Governor of the Bank of England is obliged to submit an open letter to the Chancellor of the Exchequer explaining the reason for the deviation and presenting a timetable for a return to the target.

Although most inflation targeters share these four broad features, there is considerable variation in some of the specifics. At the level of implementation, for example, central banks differ with respect to choice of price index (overall versus "core" inflation) and the particular form of the target (point versus range). At a more substantive level, inflation targeters also differ as to "goal independence": those that are only "instrument independent" pursue a target set for them by the elected government, while those that are also "goal independent" set their own targets. There is also a great deal of heterogeneity with respect to exactly what central banks communicate-and how; these differences are cataloged in great detail by Fracasso, Genberg, and Wyplosz (2003).

It is also interesting to distinguish full-fledged inflation targeters from "near-inflation targeters" on the basis of these features. For example, some central banks - particularly those of emergingmarket or post-communist countries-have set up most of the mechanics of IT, but lack the institutional means to make a long-run commitment to price stability. Carare and Stone (2003) and Stone (2003) refer to this regime as "Inflation Targeting Lite." Other central banks seem to have internalized the price stability objective without adopting all the trappings of outright IT. The Federal Reserve might be put into this category. Although it also operates under a dual mandate, in recent years price stability has been increasingly emphasized as the primary long-run goal of monetary policy. ${ }^{12}$ Nonetheless, the Federal Reserve still lacks an explicit numerical inflation target, and as discussed in Kuttner and Posen (2001), its monetary policy formulation

\footnotetext{
12 In 1988, Greenspan stated: "We should not be satisfied unless the U.S. economy is operating at high employment with a sustainable external position and above all stable prices... By price stability, I mean a situation in which households and businesses in making their saving and investment decisions can safely ignore the possibility of sustained, generalized price increases or decreases" [Greenspan (1988), emphasis added]
} 
remains considerably more opaque than that of the typical inflation targeter. ${ }^{13}$

\section{Will the Real Inflation Targeter Please Step Forward?}

The question now is how (and indeed whether) the central bank practices described above map into the various definitions of IT that have been proposed in the theoretical literature. Based on the institutional arrangements, which central banks qualify for membership in the IT club? And to what extent does this depend on the theoretical definition of IT one has in mind?

"Weak form" IT is so weak as to be almost vacuous. Under this definition, virtually every major central bank qualifies as an inflation targeter. It implies merely that the central bank acts in such a way as to eventually bring inflation back to its target, and says nothing about the nature of the policy used to get there. Thus, it would seem that the only requirement for entry into the IT club is having a reaction function coefficient of at least a certain size. And indeed since this condition is also a requirement for a well-behaved solution to conventional macro models, any country with a mean-reverting inflation rate would ipso facto qualify as an inflation targeter; only those with "unstable" inflation would fail the test. 14

It is hard to find institutional evidence that any central bank conforms to either the "strong" or "semi-strong" forms of IT. The problem is that no central bank-inflation targeter or otherwisecurrently conducts policy with reference to an explicit, publicly announced loss function or firstorder condition. Nor is there any documentary evidence to suggest that policymakers choose between different policy options on the basis of any numerical estimate of the estimated "loss" associated with the various options. Thus, on the basis of Svensson's definition of IT as an optimal targeting rule, it would seem that no central bank qualifies as a bona fide inflation targeter. ${ }^{15}$ Furthermore, even among self-

\footnotetext{
13 It is worth making a distinction between transparency in policy formulation versus transparency in implementation. The Federal Reserve has, of course, become much more transparent in the implementation of policy, especially since the practice of announcing changes in the funds rate target began in February 1994

${ }^{14}$ In backward-looking models, failing to satisfy the Taylor principle typically results in explosive inflation; in forward-looking models, it can generate indeterminacies.

${ }^{15}$ In the spirit of Friedman (1953), it might be argued that central bankers act "as if" they were minimizing a loss function, even if they were not consciously aware that fact.
}

proclaimed inflation targeters, only the Reserve Bank of New Zealand (RBNZ) publishes a forecast of the output gap, which is a key ingredient in conventional targeting rules. ${ }^{16}$

While no inflation targeter currently communicates in the language of optimization, all inflation targeters talk a great deal. Indeed, as noted above, communication is a central element of the practice of IT. Formalizing the role of this IT-induced transparency has presented a theoretical challenge, however. From an optimal control standpoint, it makes no difference whether the central bank keeps its first-order conditions to itself or explains them in detail to the public four times per year. Optimal policy will be the same either way.

One hypothesis is that transparency and accountability somehow allow the central bank to overcome the time consistency problem inherent in optimal monetary policy. One way to formalize this idea is to assume private information on the part of the central bank regarding its output or inflation objectives. Herrendorf (1998) and Faust and Svensson (2001) take this approach, as does Geraats (2002), explicitly in the context of the decision to publish a forecast. In Drazen and Masson (1994) and Agénor and Masson (1999), the private information has to do with the central bank's preferences: specifically, whether it is "strong" in the sense of assigning a low weight on output fluctuations in its loss function relative to a "weak" central bank. In the context of both sets of models, transparency plays a direct role in helping to reveal the unobserved private information. Less formally, King (1997) has argued that transparency, accountability, and a clearly defined objective all enhance central bank "credibility," defined as the ability to convince the private sector that it will carry out policies that may be time inconsistent, and thus implement the optimal statecontingent rule.

\section{ESTIMATED POLICY RULES FOR THREE INFLATION TARGETERS AND THE FED}

We now turn to the question of how well the behavior of IT central banks can be characterized by simple policy rules of the sort discussed earlier in section 2 . We first consider conventional instrument rules relating the relevant short-term interest

\footnotetext{
16 Svensson (2000) contends this is an essential requirement for IT: "policy decisions are consistently motivated with reference to published inflation and output(-gap) forecasts."
} 
rate to macroeconomic objectives, i.e., output and inflation. Specific targeting rules-that is, equations describing the optimal trade-off between output and inflation-are taken up later in the section.

Ideally, one would want to use these estimates to say which of the definitions of IT from section 3 best described the central banks' behavior. This is hard to do econometrically, unfortunately. Estimates of instrument rules or reaction functions may reveal something about whether the Taylor principle is satisfied, but without a fully and correctly specified macro model, it is difficult (if not impossible) to distinguish between optimal and ad hoc behavior on the part of the central bank. Similarly, the distinction between discretionary and precommitment-based policy is a very subtle one to discern empirically, although Kuttner and Posen (1999) suggest that precommitment-like behavior may explain the observed decline in inflation persistence among inflation targeters. At the very least, however, such estimates can provide some information as to how closely banks' behavior conforms to simple rules of one form or another.

This is, of course, not the first effort to describe central banks' behavior in terms of simple policy rules. What distinguishes this paper from much of the other work in the area is its use of the central banks' own published inflation and output forecasts, rather than econometric proxies for the relevant expectations. ${ }^{17}$ This approach has a number of compelling advantages. First, it greatly simplifies the econometrics, reducing the data requirements and obviating the need for the two-stage GMM method used by Clarida, Galí, and Gertler (2000). Second, the central banks' own forecasts are likely to be more reliable than those based on simple econometric methods. ${ }^{18}$ One reason is that the central banks' forecasts undoubtedly incorporate a great deal of information not in the macro time series, as well as informal "judgment" as to the most likely outcomes. It is this kind of an information

\footnotetext{
${ }^{17}$ Jansson and Vredin (2003) and Berg, Jansson, and Vredin (2002) use Riksbank forecasts in their analysis, and Huang, Margaritis, and Mayes (2001) utilize the RBNZ's published projections. For the United States, McNees $(1986,1992)$ uses the Federal Reserve's internal Green Book forecasts in estimating a forward-looking reaction function, an approach that has been adopted by Orphanides (2001) and Boivin (2003), among others.

${ }^{18}$ All three central banks regularly assess their own forecasting performance: see, for example, McCaw and Ranchhod (2002) for New Zealand, Pagan (2003) (and the references cited therein) for the Bank of England, and the "Materials for Assessing Monetary Policy" appendix to the Riksbank's March Inflation Report.
}

advantage that Romer and Romer (2000) suggest accounts for the superior performance of the Federal Reserve's Green Book forecasts. Finally, the published forecasts presumably embody appropriate assumptions about the central banks' intended policy actions. Naive, unconditional econometric forecasts, on the other hand, may imply a path of policy at odds with central banks' intentions.

The analysis in this section focuses on three central banks: the RBNZ, the Bank of England, and Sweden's Riksbank. These three were chosen because they are the three inflation targeters with the longest track record of published, quantitative forecasts. Other seasoned inflation targeters, such as the Reserve Bank of Australia and the Bank of Canada, make use of detailed projections internally, but these projections have not been made available publicly. Instead, their published reports contain only more qualitative, impressionistic assessments of the outlook for inflation and output, which are less amenable to quantitative analysis.

Although all three of the central banks under study report some sort of a forecast every quarter, the nature of these forecasts differs considerably across banks. Since 1997, the Bank of England's Inflation Report has consistently reported projections for four-quarter inflation and real gross domestic product (GDP) growth (mean, median, mode, and a measure of uncertainty) for an eight-quarter forecast horizon. The Riksbank, since 1992, has published forecasts for Q4/Q4 real GDP growth and December/ December consumer price index (CPI) inflation for the current year and the two following "out" years. The RBNZ reports projections over a longer forecast horizon than the other central banks, with some forecasts going out as long as 15 quarters. The RBNZ is also unique in that it is the only central bank ever to have published estimates and forecasts of the output gap - a key ingredient in typical targeting and instrument rules.

The three central banks do differ somewhat as to how they express their inflation targets. Over the period covered by the analysis in this paper, the Bank of England had a point target of 2.5 percent for the retail price index less mortgage-related items (known as the RPIX). The RBNZ's current Policy Targets Agreement (PTA) currently specifies a 1 to 3 percent range for overall CPI inflation. (From 1997 through 2002:Q3, the target range was 0 to 3 percent for core CPIX inflation.) The Sveriges Riksbank has a point target of 2 percent for overall CPI inflation, with a \pm 1 percent tolerance around that target. 
The policy assumptions underlying the three central banks' forecasts also differ on one key dimension. The Bank of England and Riksbank both report constant-interest-rate forecasts, in which the interest rate set by policy is assumed to remain unchanged over the forecast horizon. Leitemo (2003) has interpreted this as a policy rule in which the current interest rate is set at a level consistent with attaining the inflation target. ${ }^{19}$ Vredin (2003) contends that interpretation is inconsistent with the Riksbank's policy; indeed, its Inflation Report has at times explicitly acknowledged that a significant divergence between the forecast and the target would require a change in policy. As discussed below, however, the Bank of England's and the Riksbank's two-yearahead forecasts come reasonably close to their stated targets, at least since 1997. This observation, along with the well-known instability problems associated with constant-interest-rate rules, led Vredin (2003) to question whether these central banks' forecasts represent true constant-interest-rate forecasts. ${ }^{20}$ Unlike other inflation targeters, the RBNZ conditions its forecasts on the time-varying interest rate given by the inflation-forecast-based rule used in the staff macro model. ${ }^{21}$ In doing so, the RBNZ avoids the difficult methodological issues associated with constant-interest-rate projections and provides an outlook for interest rates and the economy that is arguably more coherent than those of the other central banks.

There are also subtle differences in the timing of the forecasts relative to the policy decisions. The Riksbank and the RBNZ both publish their forecasts on the same day on which interest rate decisions are made. Consequently, these two central banks' forecasts are conditioned almost by construction (given the time required to put together a new forecast) on the preceding period's interest rate. By contrast, the Bank of England publishes its inflation report two weeks after a Monetary Policy Committee meeting, and as a result its forecasts are conditioned

\footnotetext{
${ }^{19}$ Leitemo (2003) points out that such a constant-interest-rate rule is time inconsistent, as the interest rate required to achieve the target would be expected to change as the horizon advances, and derives a method for calculating the time-consistent equilibrium under such a constant interest rate rule.

20 Noting that the Riksbank's two-year inflation forecast, since 1997 , has never fallen outside of the 1 to 3 percent range, Leeper (2003) also questions the credibility of the Riksbank's constant-interest-rate assumption.

21 Details of the RBNZ's IFB rule can be found in the appendix to Drew and Plantier (2000).
}

on the current period's policy action. Thus, the Riksbank and RBNZ forecasts can be taken as predetermined with respect to the current-period interest rate, while those of the Bank of England cannot.

It is interesting to note that an explicit reaction function or instrument rule does not figure prominently in any of the three central banks' official publications, which tend to focus instead on the outlook for inflation, relative to its target, and a discussion of economic conditions more generally. This is not to say that instrument rules have been entirely ignored, however. Since 2000, the March issue of the Riksbank's Inflation Report has included an assessment of monetary policy using an econometrically estimated "rule of thumb" based on the Riksbank's own inflation forecasts. 22 According to Archer (2003), a Taylor-style rule is used internally at the RBNZ for assessing various policy options, and one (the May 2001) issue of the Monetary Policy Statement actually included such a rule-based assessment. Nikolov (2002) reports that Bank of England staff and the Monetary Policy Committee periodically review the implications of a variety of policy rules, although the output gap data used to implement these rules are not made public.

For comparison, we also include an analysis of Federal Reserve behavior based on the internal forecasts contained in the unpublished "Green Books," which are made public after a five-year lag. ${ }^{23}$ This comparison is inexact at best, however, because the policy assumptions underlying the Green Book forecasts differ fundamentally from those embodied in the inflation targeters' forecasts. In particular, while some plausible path for the funds rate target is assumed in the Green Book, this policy does not necessarily correspond to the FOMC's intentions; nor is it generally the case over the period analyzed that the policy brings inflation back to a fixed target by the end of the forecast horizon. ${ }^{24}$

\footnotetext{
${ }^{22}$ The research underlying the rule of thumb described in the Inflation Report can be found in Jansson and Vredin (2003) and Berg, Jansson, and Vredin (2002).

${ }^{23}$ Pre-1997 Green Book data can be found at www.phil.frb.org/econ/forecast/greenbookdatasets.html.

${ }^{24}$ The baseline assumption is typically (though not always) a constant nominal funds rate; see Reifschneider, Stockton, and Wilcox (1997). Another possibility would be to use the biannually published "central tendency" forecast of the FOMC. Although this may conform to the FOMC's intentions more closely than the Green Book forecasts, the conditioning assumptions (inflation objective, interest rate path) are no clearer.
} 


\section{Figure 1}

\section{Inflation Forecasts and Targets}
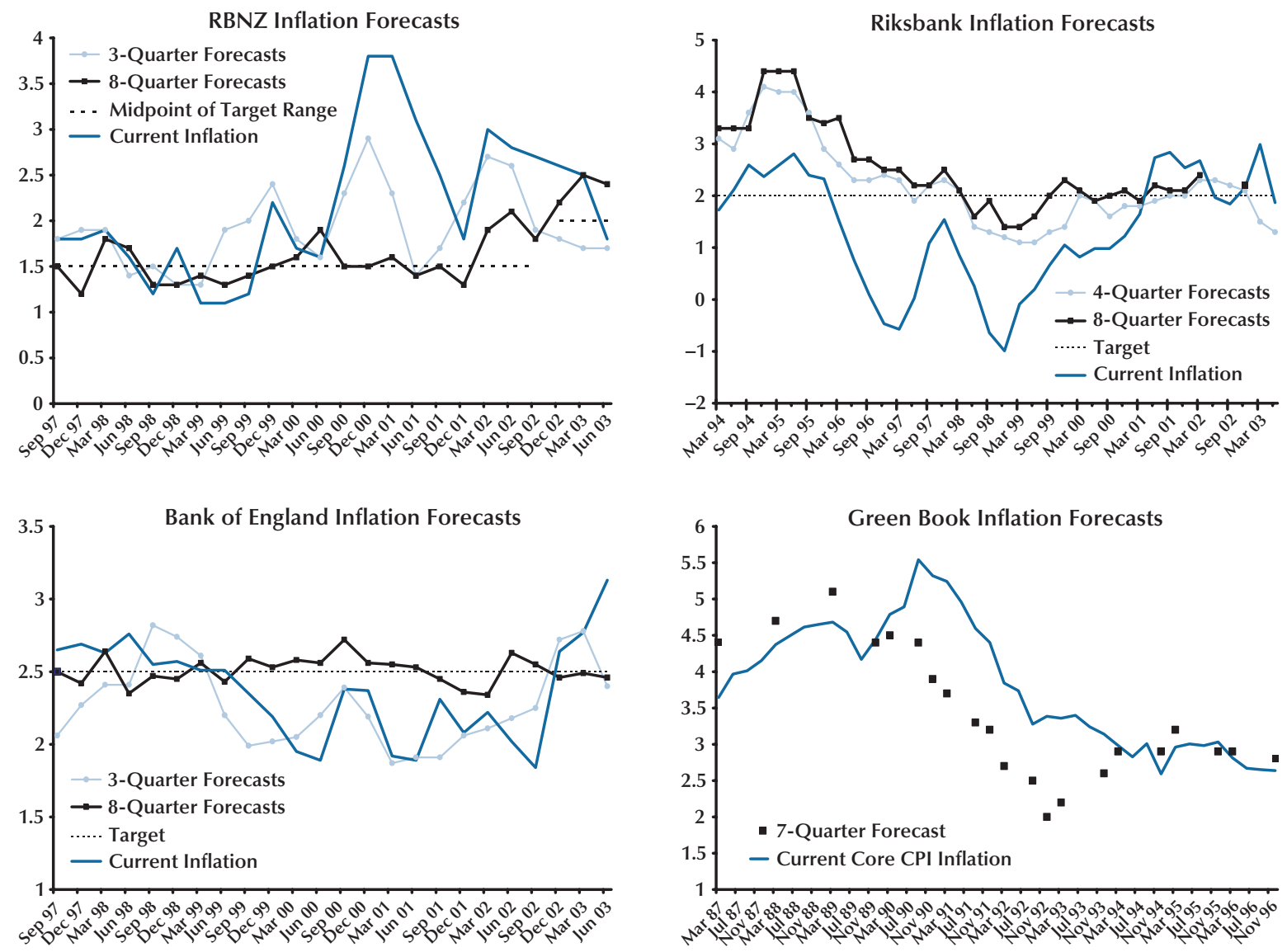

\section{Properties of the Inflation Forecasts}

We begin by simply examining the properties of the central banks' inflation forecasts. Figure 1 displays time series of the medium- and long-run forecasts, along with the current year-over-year inflation rate and (except for the United States) the inflation target. The figure reveals considerable variation in the relatively short-run three-quarterahead forecasts. Not surprisingly, the eight-quarterahead forecasts tend to fall much closer to the target. Sweden in the early- to mid-1990s is something of an exception, however, with even the two-year-ahead forecasts well above the target until 1996.25 The Fed's forecast, shown in the lower right-hand panel, also

\footnotetext{
${ }^{25}$ According to Berg, Jansson, and Vredin (2002), this early stage of IT was one in which the Riksbank was still struggling to establish the credibility of its target.
}

exhibits a great deal of variation, which reached 5 percent in 1989 before falling to less than 2 percent with the disinflation that accompanied the 1991-92 recession. ${ }^{26}$

Another way to look at the same set of data is to plot the forecast change in the inflation rate against the deviation of current inflation from its target. Forecasts that implied a return to the target within the specified horizon would fall along a -45 degree line; for example, inflation 1 percent above target would imply a -1 percent forecast change. The eightquarter-ahead forecasts for the RBNZ fall reasonably close to this -45 degree line, as shown in the upper left-hand panel of Figure 2. For the United Kingdom,

26 The Green Book's forecast horizon over the 1986-96 period varied between five and nine quarters, which is somewhat shorter than that of the inflation targeters. A seven-quarter-ahead horizon was therefore chosen so as not to lose too many observations. 


\section{Figure 2}

\section{Target Reversion of Inflation Forecasts}
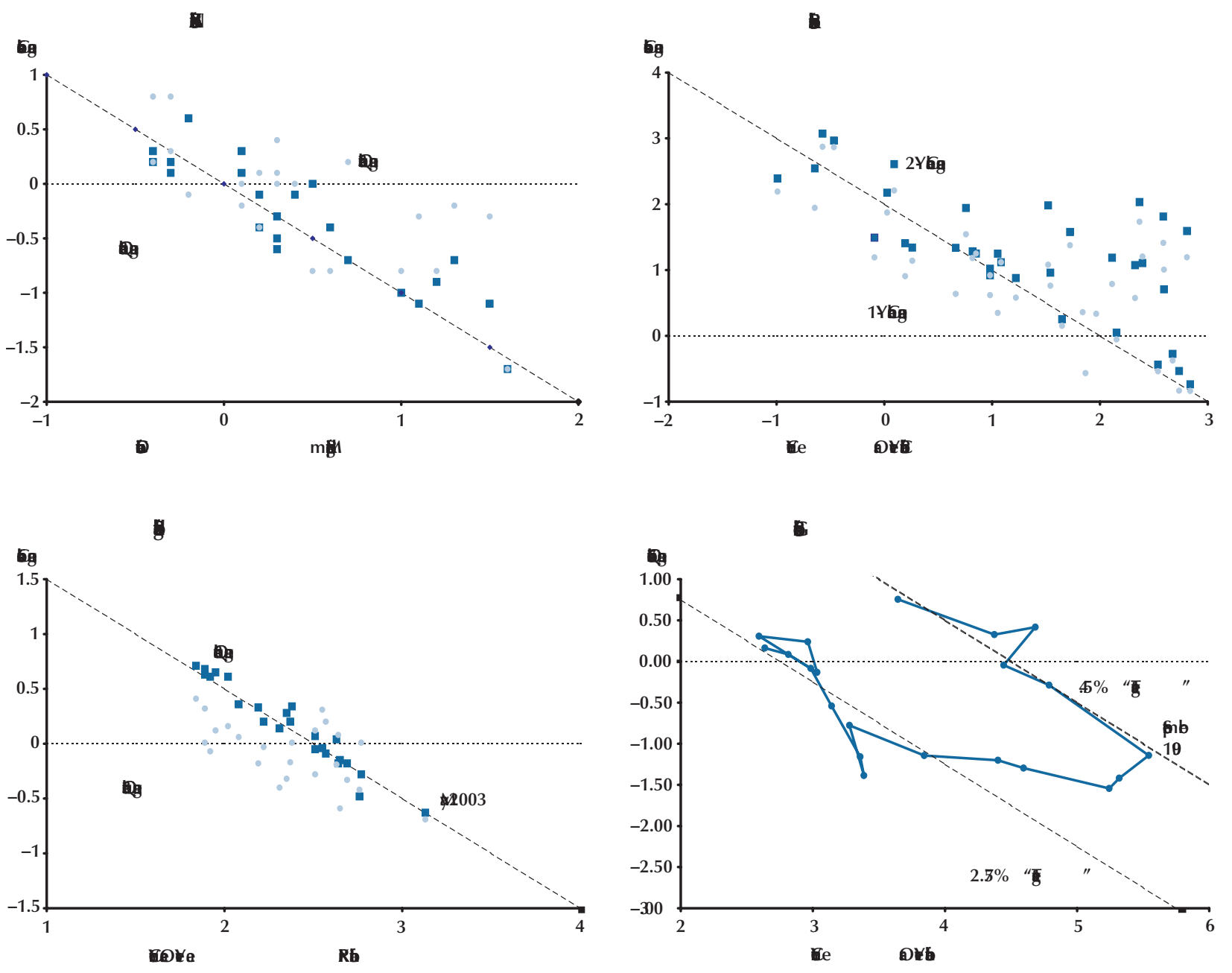

the eight-quarter-ahead forecasts (depicted in the lower left-hand panel) lie very close to the -45 degree line, which is perhaps to be expected given the way in which the Bank of England's forecasts incorporate recent policy actions. The Riksbank's forecasts in the upper right-hand panel are considerably more spread out, in part reflecting the experience in the mid-1990s when inflation was above its target and expected to rise still further. For all three inflation targeters, the three-quarter-ahead forecast inflation changes generally lie some distance from the -45 degree line, suggesting that most deviations from the inflation target are not expected to be fully reversed at such a short horizon.

The Fed's inflation forecasts, shown in the lower right-hand panel, display an interesting pattern.
Prior to December 1990, the long-horizon Green Book forecasts tended to revert to a "target" of approximately 4.5 percent, depicted by the higher of the two -45 degree lines. (As noted above, this "target" reflects the assumptions implicit in the Green Book, rather than the intentions of the FOMC.) But as inflation fell during the course of the recession, the implicit "target" in the Green Book seems to have shifted down to roughly 2.75 percent.

\section{Instrument Rules: Two Conventional Specifications}

This section presents estimates of conventional instrument rules for the four central banks under study. We begin with the simplest of the simple rules: 


\section{Table 1}

\section{Estimates of the Taylor Specification of the Instrument Rule}

Dependent variable $=$ policy interest rate, $i$

\begin{tabular}{|c|c|c|c|c|c|c|c|}
\hline & \multirow[b]{2}{*}{$N$} & \multicolumn{4}{|c|}{ Coefficient on } & \multirow[b]{2}{*}{ Adjusted $R^{2}$} & \multirow{2}{*}{$\begin{array}{l}\text { LM test for } \\
\text { 2nd order } \\
\text { auto- } \\
\text { correlation }\end{array}$} \\
\hline & & Intercept & Output gap & Inflation & Lagged $i$ & & \\
\hline $\begin{array}{l}\text { New Zealand } \\
\text { 1997:Q4-2003:Q2 }\end{array}$ & 23 & $\begin{array}{c}1.14 \\
(0.78)\end{array}$ & $\begin{array}{c}0.25 \\
(0.17)\end{array}$ & $\begin{array}{c}-0.04 \\
(0.23)\end{array}$ & $\begin{array}{l}0.83^{* * * *} \\
(0.13)\end{array}$ & 0.64 & $\begin{array}{l}12.6 \\
0.001\end{array}$ \\
\hline $\begin{array}{l}\text { Sweden } \\
\text { 1994:Q1-2003:Q2 }\end{array}$ & 38 & $\begin{array}{c}0.17 \\
(0.17)\end{array}$ & $\begin{array}{l}-0.63^{* * *} \\
(0.13)\end{array}$ & $\begin{array}{l}0.27^{* * *} \\
(0.05)\end{array}$ & $\begin{array}{l}0.99 * * * \\
(0.04)\end{array}$ & 0.96 & $\begin{array}{l}8.43 \\
0.014\end{array}$ \\
\hline $\begin{array}{l}\text { United Kingdom } \\
\text { 1997:Q4-2003:Q2 }\end{array}$ & 23 & $\begin{array}{c}-0.79 \\
(0.61)\end{array}$ & $\begin{array}{c}-0.43^{*} \\
(0.22)\end{array}$ & $\begin{array}{c}0.27 \\
(0.28)\end{array}$ & $\begin{array}{l}1.12^{* * *} \\
(0.11)\end{array}$ & 0.90 & $\begin{array}{l}3.25 \\
0.197\end{array}$ \\
\hline $\begin{array}{l}\text { United States } \\
\text { 1987:Q1-1996:Q4 }\end{array}$ & 40 & $\begin{array}{l}0.68^{* * *} \\
(0.33)\end{array}$ & $\begin{array}{l}0.32^{* * *} \\
(0.08)\end{array}$ & $\begin{array}{c}0.10 \\
(0.14)\end{array}$ & $\begin{array}{l}0.81 * * * \\
(0.07)\end{array}$ & 0.95 & $\begin{array}{l}7.06 \\
0.029\end{array}$ \\
\hline
\end{tabular}

NOTE: ${ }^{* * *} / * * / *$ Indicate significance at the $1 / 5 / 10$ percent levels, respectively. Estimation is by ordinary least squares. Numbers in parentheses are standard errors. The LM test statistic for second-order autocorrelation is $N$ times the $R^{2}$ from a regression of the residual onto all the regressors from the original regression and two lags of the residual. The $p$ value from the $\chi^{2}$ distribution is reported underneath the test statistic. For Sweden and the United Kingdom, the policy rate corresponds to the repo rate. For New Zealand, it is the 90-day bank rate, and for the United States, it is the federal funds rate. For New Zealand and the United Kingdom, the inflation rate used in the regression is the current-quarter "forecast" of four-quarter inflation. For Sweden, it is the four-quarter percentage change in the CPI. For the United States, it is the four-quarter percentage change in the CPI, excluding food and energy. Proxies for the output gap are constructed by accumulating the difference between the forecast growth rates of real GDP and an assumed rate of potential growth. The data appendix contains additional details.

the classic Taylor (1993) rule, giving the policy rate as a function of the current output gap and inflation deviation,

$$
\text { (4) } i_{t}=(1-\rho) i^{*}+\beta x_{t, t}+\gamma\left(\pi_{t}-\pi^{*}\right)+\rho i_{t-1}+e_{t} \text {, }
$$

where $x_{t, t}$ is the current estimate of the current output gap, $\pi_{t}$ is the current four-quarter inflation rate, $\pi^{*}$ is the target inflation rate, and $i^{*}$ is the steadystate nominal rate of interest (i.e., the inflation target plus the equilibrium real rate of interest). The only addition to the canonical Taylor specification is the lagged interest rate term, whose conventional interpretation is in terms of interest rate "smoothing"the partial adjustment of the policy instrument toward some underlying target rate. In this parameterization, the long-run response of the nominal rate to inflation is $\gamma /(1-\rho)$.

This is the point at which empirical research on policy rules must confront the uncomfortable fact that no central bank, except the RBNZ, consistently reports an estimate of the output gap, $x_{t, t} \cdot{ }^{27}$

${ }^{27}$ The RBNZ reported quarterly output gap projections in its Monetary Policy Statements from December 1997 through November 1999 and again from December 2000 through March 2001. Annual averages have been published consistently throughout the 1997-2003 period.
As a practical matter, this obviously complicates any effort to model central bank behavior in terms of a policy rule involving the output gap.

Rather than abandon the task at this point, we proceed by constructing a proxy for the output gap. Our approach is to back out an implicit estimate of the output gap using the central banks' projections of real GDP growth. Two assumptions are needed to make this work: (i) an estimate of the growth rate of potential output and (ii) a terminal condition, i.e., the value of the output gap at the end of the forecast horizon. For (i), we make an educated guess as to the assumed growth rate of potential output, using information gleaned from published central bank sources. For (ii), we assume the output gap reverts to zero at the end of the forecast horizon, unless published information suggests otherwise. With these assumptions, a real-time estimate of the output gap can be constructed as the accumulated difference between the forecasts of real GDP growth and the assumed potential growth rate. Further details on the construction of the output gap proxy can be found in the appendix.

The results, shown in Table 1, suggest a simple rule like (4) is a poor description of policy for all 


\section{Table 2}

\section{Estimates of the Forward-Looking Instrument Rule}

Dependent variable $=$ policy interest rate, $i$

\begin{tabular}{|c|c|c|c|c|c|c|c|c|}
\hline & \multirow[b]{2}{*}{$N$} & \multicolumn{5}{|c|}{ Coefficient on } & \multirow[b]{2}{*}{ Adjusted $R^{2}$} & \multirow{2}{*}{$\begin{array}{l}\text { LM test for } \\
\text { 2nd order } \\
\text { auto- } \\
\text { correlation }\end{array}$} \\
\hline & & Intercept & $\begin{array}{c}\text { Current } \\
\text { output gap }\end{array}$ & $\begin{array}{l}\text { Growth } \\
\text { forecast }\end{array}$ & $\begin{array}{l}\text { Inflation } \\
\text { forecast }\end{array}$ & Lagged $i$ & & \\
\hline $\begin{array}{l}\text { New Zealand } \\
\text { 1997:Q4-2003:Q2 }\end{array}$ & 23 & $\begin{array}{l}1.20 \\
(0.61)\end{array}$ & $\begin{array}{l}0.42^{* *} \\
(0.19)\end{array}$ & $\begin{array}{c}0.50^{*} \\
(0.26)\end{array}$ & $\begin{array}{l}1.22 * * \\
(0.53)\end{array}$ & $\begin{array}{l}0.75^{* * *} \\
(0.10)\end{array}$ & 0.78 & $\begin{array}{l}9.00 \\
0.011\end{array}$ \\
\hline $\begin{array}{l}\text { Sweden } \\
\text { 1994:Q1-2003:Q2 }\end{array}$ & 38 & $\begin{array}{c}0.06 \\
(0.41)\end{array}$ & $\begin{array}{l}-0.18 \\
(0.13)\end{array}$ & $\begin{array}{l}0.31^{* *} \\
(0.12)\end{array}$ & $\begin{array}{l}0.65^{* * *} \\
(0.10)\end{array}$ & $\begin{array}{l}0.77^{* * *} \\
(0.05)\end{array}$ & 0.97 & $\begin{array}{l}3.95 \\
0.138\end{array}$ \\
\hline $\begin{array}{l}\text { United Kingdom } \\
\text { 1997:Q4-2003:Q2 }\end{array}$ & 23 & $\begin{array}{l}-2.34 \\
(1.39)\end{array}$ & $\begin{array}{l}-0.06 \\
(0.32)\end{array}$ & $\begin{array}{c}0.53 \\
(0.39)\end{array}$ & $\begin{array}{c}0.09 \\
(0.37)\end{array}$ & $\begin{array}{l}1.19^{* * *} \\
(0.13)\end{array}$ & 0.90 & $\begin{array}{l}4.68 \\
0.096\end{array}$ \\
\hline $\begin{array}{l}\text { United States } \\
\text { 1987:Q1-1996:Q4 }\end{array}$ & 40 & $\begin{array}{l}-0.62 \\
(0.52)\end{array}$ & $\begin{array}{l}0.39 * * * \\
(0.08)\end{array}$ & $\begin{array}{c}0.20 \\
(0.17)\end{array}$ & $\begin{array}{l}0.50^{* * *} \\
(0.15)\end{array}$ & $\begin{array}{l}0.70 * * * \\
(0.06)\end{array}$ & 0.96 & $\begin{array}{l}4.61 \\
0.100\end{array}$ \\
\hline
\end{tabular}

NOTE: $* * * / * * / *$ Indicate significance at the $1 / 5 / 10$ percent levels, respectively. Estimation is by ordinary least squares. Numbers in parentheses are standard errors. For New Zealand, Sweden, and the United Kingdom, the inflation forecast is the forecast change in the target inflation rate over the subsequent four quarters, minus the inflation target (or the midpoint of the range, in the case of New Zealand). For the United States, it is simply the forecast percentage change in the CPI over the subsequent four quarters, so the regression intercept also includes any implicit inflation target. The growth forecast is for real GDP growth over the subsequent four quarters, or in the case of New Zealand, the change in the output gap. See also notes to Table 1.

four central banks. For New Zealand, the coefficient on inflation is effectively zero, and none of the coefficients (except that on the lagged interest rate) is statistically significant. The results are slightly better for Sweden, which at least exhibits a statistically significant and positive response to inflation. The coefficient on the output gap has the wrong (negative) sign, however, and it is statistically significant. The results are also unsatisfactory for the United Kingdom. Like Sweden, the output gap coefficient is significant, but has the wrong sign. The inflation coefficient has the right sign, but it is statistically insignificant. ${ }^{28}$ In the United States, we find a significant, positive coefficient on the output gap, but the coefficient on inflation is small and insignificant. The estimated $\rho$ parameter on the lagged interest rate is large and highly significant in all cases, ranging from 0.81 for the United States to 1.12 for the United Kingdom, suggesting an implausibly high degree of interest rate smoothing. The $R^{2}$ are highbut only because of the explanatory power of the lagged interest rate.

An alternative to Taylor's specification, in the

${ }^{28}$ One reason for the poor results could be the lack of any significant variation in inflation or the output gap since 1997. Ironically, the success of the Bank of England's IT policy seems to have made it more difficult to estimate a policy rule. spirit of Clarida, Galí, and Gertler (2000), is to use forecasts of inflation and the output gap, or alternatively the current output gap estimate and the real GDP forecast,

$$
\begin{aligned}
i_{t}= & (1-\rho) i^{*}+\beta_{1} x_{t, t}+\beta_{2} \Delta y_{t+k, t} \\
& +\gamma\left(\pi_{t+k, t}-\pi^{*}\right)+\rho i_{t-1}+e_{t},
\end{aligned}
$$

where $\Delta y_{t+k, t}$ and $\pi_{t+k, t}$ are the central bank's forecasts of real GDP growth and inflation over the subsequent $k$ quarters. This specification is attractive, as it captures rational, forward-looking behavior on the part of the central bank. In addition, by explicitly including a forecast of inflation, the coefficients on the output terms are readily interpreted in terms of an output stabilization objective. By contrast, the output gap may appear in the Taylor specification as a predictor of inflation and may not imply a weight on output stabilization per se.

Results from estimating (5) appear in Table 2, with the horizon $k$ set to four quarters. The results are generally somewhat better than for the backwardlooking Taylor specification. The equation works very well for New Zealand, in the sense that the coefficients on the current gap, the growth forecast, and expected inflation are all significant and have the expected signs. It also works reasonably well for Sweden, where the parameter estimates on output 
growth and year-ahead inflation are both highly significant. ${ }^{29}$ The United Kingdom still yields poor results, however. None of the coefficients is significant, although the coefficients on forecast GDP growth and inflation at least have the correct signs. For the United States, the output gap and the inflation forecast both have the correct signs and are significant; in fact, the estimates look a lot like those reported in Clarida, Gali, and Gertler (2000). The Taylor principle seems to be satisfied for all but the United Kingdom. Interestingly, the implied long-run response of the interest rate to inflation is much larger for New Zealand and Sweden (4.88 and 2.82, respectively) than for the United States (1.34). But this may reflect a difference in the nature of the Green Book forecast which, unlike the inflation targeters', has not assumed a reversion of inflation toward an unchanged target. The estimated coefficients on the lagged interest rates are still quite large, ranging from 0.70 for the United States to 1.19 for the United Kingdom.

\section{Instrument Rules: A "Reaction to News" Specification}

One of the consistently unsatisfying results from conventional instrument rule estimates, like those presented above, is that the large estimates of $\rho$ imply an extremely high degree of interest rate smoothing. Rudebusch (2002) argues that this reflects the omission of highly serially correlated variables from the instrument rule, rather than interest rate smoothing per se.

In a similar vein, Svensson (2003) shows that the optimal instrument rule for an inflation forecast targeter has the form

$$
\begin{aligned}
i_{t}= & (1-\rho) i^{*}+\beta x_{t+k, t}+\gamma\left(\pi_{t+k, t}-\pi^{*}\right) \\
& +\phi z_{t+k, t}+e_{t},
\end{aligned}
$$

where $z_{t+k, t}$ is the central bank's forecast of some appropriate "judgmental" adjustment term, which represents an omitted variable in the conventional instrument rule specification. ${ }^{30}$ Indeed, as discussed above in section 2 , it is the presence of these unobserved judgment terms that leads Svensson to argue

\footnotetext{
${ }^{29}$ Very similar results are reported in Berg, Jansson, and Vredin (2002), who also find that the forecast of output growth is significant

30 Svensson's equation actually contains separate terms involving linear combinations of one- and two-period-ahead forecasts of $z$, interpreted as a vector of judgment terms. But for our purposes, a single $z$ term suffices.
}

for the superiority of formulating policy on the basis of targeting rules. Omitted, serially correlated judgment terms could, therefore, lead to a spuriously high degree of measured interest rate smoothing.

Our solution to this issue is a novel approach to estimating an instrument rule that, in principle, eliminates the serial correlation in the omitted judgment term and allows for a clearer distinction between interest rate smoothing and reaction to this omitted variable. The innovation is to examine the response of the policy rate to the "news" contained in the revisions in expectations embodied in the central banks' inflation and output forecasts.

This approach is derived quite simply by first adding a lagged interest rate term to the instrument rule (6),

$$
\begin{aligned}
i_{t}= & (1-\rho) i^{*}+\beta x_{t+k, t}+\gamma\left(\pi_{t+k, t}-\pi^{*}\right) \\
& +\phi Z_{t+k, t}+\rho i_{t-1}+e_{t},
\end{aligned}
$$

and projecting it onto information available to the central bank at time $t-1$,

$$
\begin{aligned}
i_{t, t-1}= & (1-\rho) i^{*}+\beta x_{t+k, t-1}+\gamma\left(\pi_{t+k, t-1}-\pi^{*}\right) \\
& +\phi Z_{t+k, t-1}+\rho i_{t-1}+e_{t, t-1}
\end{aligned}
$$

Subtracting (8) from (7) gives

$$
\text { (9) } \begin{aligned}
i_{t}-i_{t, t-1}= & \beta\left(x_{t+k, t}-x_{t+k, t-1}\right)+\gamma\left(\pi_{t+k, t}-\pi_{t+k, t-1}\right) \\
& +\phi\left(z_{t+k, t}-Z_{t+k, t-1}\right)+e_{t}-e_{t, t-1} .
\end{aligned}
$$

Thus, the difference between the current policy setting, $i_{t}$, and the expected policy setting as of the previous period, $i_{t, t-1}$, depends entirely on the revisions in the $k$-period-ahead expectations of the output gap, inflation, and the unobserved $z$. Taking the difference relative to the previous period's expectation makes the interest rate smoothing term, $\rho i_{t-1}$, disappear. More importantly, if the central bank's forecasts are rational, then the unobserved revision in the expectation of $z$ should, by the law of iterated projections, be unforecastable-and consequently serially uncorrelated. Similarly, any residual serial correlation in the $e_{t}$ term will also disappear, leaving a specification free from the usual econometric problems that normally afflict estimated instrument rules. 31

Access to published central bank forecasts makes it quite easy to implement this approach. Because of the overlapping nature of these forecasts, the

\footnotetext{
${ }^{31}$ While this specification resembles that of English, Nelson, and Sack (2002), what distinguishes our approach is its emphasis on forecast revisions.
} 


\section{Table 3}

\section{Volatility of Forecast Revisions and Interest Rate Changes}

\begin{tabular}{lccc} 
& \multicolumn{3}{c}{ Standard deviation of } \\
\cline { 2 - 4 } & $\begin{array}{c}\text { Four-quarter-ahead } \\
\text { real GDP forecast revision }\end{array}$ & $\begin{array}{c}\text { Four-quarter-ahead } \\
\text { inflation forecast revision }\end{array}$ & $\begin{array}{c}\text { Quarterly change } \\
\text { in policy rate }\end{array}$ \\
\hline New Zealand, 1997:Q4-2003:Q2 & 0.58 & 0.30 & 0.78 \\
Sweden, 1994:Q1-2003:Q2 & 0.34 & 0.32 & 0.48 \\
United Kingdom, 1997:Q4-2003:Q2 & 0.35 & 0.31 & 0.40 \\
United States, 1987:Q1-1996:Q4 & 0.41 & 0.28 & 0.53
\end{tabular}

NOTE: The forecast revisions represent the difference between the four-quarter-ahead forecast made in quarter $t$ and the five-quarterahead forecast made in quarter $t-1$. The real GDP and inflation forecasts are both for four-quarter growth rates. For New Zealand, the figure reported for the policy rate is the standard deviation of the policy rate forecast error, $i_{t}-i_{t, t-1}$. The standard deviation of the raw change in the policy rate, $\Delta i_{t}$, is 0.80 .

revisions in expectations are calculated quite simply as the difference between the current quarter's $k$ period-ahead forecast and the previous quarter's $k+1$-period-ahead forecast. This approach also ameliorates the problem with the unobserved output gap. The output gap forecast can be written as the difference between a forecast of real GDP and a forecast for potential output - or, equivalently, the difference between accumulated real GDP growth and potential growth forecasts. If one is willing to ignore quarterly revisions in potential growth forecasts on the grounds that these are likely to be small relative to the forecast revisions in output growth, then the accumulation of the revisions to real GDP growth forecasts can be substituted for the output gap forecast revisions.

The only remaining issue is what to use for $i_{t, t-1}$, the previous period's forecast of the current interest rate. For the RBNZ, the solution is quite simple, as the interest rate projections underlying the inflation projections are published. In this case, $i_{t, t-1}$ is just data. The solution is also straightforward for the Riksbank and the Bank of England. If these banks' stated policies of maintaining a constant interest rate over the forecast horizon were accurate (and credible), then $i_{t, t-1}$ would simply equal $i_{t-1}$, leaving

$$
\begin{aligned}
\Delta i_{t}= & \beta\left(x_{t+k, t}-x_{t+k, t-1}\right)+\gamma\left(\pi_{t+k, t}-\pi_{t+k, t-1}\right) \\
& +\phi\left(z_{t+k, t}-z_{t+k, t-1}\right)+e_{t}-e_{t, t-1},
\end{aligned}
$$

i.e., the change in the policy rate as a function of "news" about inflation and the output gap. The resemblance to Hall's (1978) formulation of the permanent income hypothesis is not coincidental.
Like a rational consumer, a central bank formulating policy on the basis of efficient forecasts of its target variables should satisfy an analogous set of orthogonality conditions. As a result, the central bank should respond only to the news embodied in its forecast revisions, and not to information that was already known at time $t-1$.

For the reasons discussed above, however, the assumption of a constant interest rate is not realistic, even for those central banks nominally adhering to a constant interest rate rule. It is nonetheless possible to derive a specification similar to (10) for the case of a time-varying (but unpublished) interest rate path. To do so requires adding $i_{t, t-1}-i_{t-1}$ to both sides of (9), so that $\Delta i_{t}$ appears on the left-hand side; assuming $x_{t+k-1, t-1} \approx x_{t+k, t-1}$ (and likewise for $\pi$ and $z$ ), the $i_{t, t-1}-i_{t-1}$ on the right-hand side becomes $\rho \Delta i_{t-1}-$ $e_{t-1}+e_{t, t-1}$. With this modification, equation (9) becomes

$$
\begin{aligned}
\Delta i_{t}= & \beta\left(x_{t+k, t}-x_{t+k, t-1}\right)+\gamma\left(\pi_{t+k, t}-\pi_{t+k, t-1}\right) \\
& +\phi\left(z_{t+k, t}-Z_{t+k, t-1}\right)+\rho \Delta i_{t-1}+e_{t}-e_{t, t-1},
\end{aligned}
$$

the main difference from (10) being the reappearance of the interest rate smoothing term, $\rho \Delta i_{t-1}$.

Table 3 reports the standard deviation of the forecast revisions and the change in the policy rate. Inflation forecast revisions are very similar in magnitude across the four central banks. Output growth forecasts are somewhat more volatile for New Zealand, which may explain the relatively high degree of variability in that country's short-term interest rate. The United Kingdom's interest rate, on the other hand, is considerably less volatile, despite 


\section{Table 4}

\section{Estimates of the "Reaction to News" Specification of the Instrument Rule}

Dependent variable $=$ change in policy rate: $\Delta i_{t}$, or $i_{t}-i_{t, t-1}$ for New Zealand

\begin{tabular}{|c|c|c|c|c|c|c|}
\hline & \multirow[b]{2}{*}{$N$} & \multicolumn{3}{|c|}{ Coefficient on } & \multirow[b]{2}{*}{ Adjusted $R^{2}$} & \multirow{2}{*}{$\begin{array}{l}\text { LM test for } \\
\text { 2nd order } \\
\text { auto- } \\
\text { correlation }\end{array}$} \\
\hline & & Output news & Inflation news & $\Delta i_{t-1}$ or $i_{t-1}-i_{t-1, t-2}$ & & \\
\hline \multirow[t]{2}{*}{$\begin{array}{l}\text { New Zealand } \\
\text { 1997:Q4-2003:Q2 }\end{array}$} & 21 & $\begin{array}{c}0.36 \\
(0.22)\end{array}$ & $\begin{array}{l}1.45^{* * *} \\
(0.46)\end{array}$ & - & 0.39 & $\begin{array}{l}1.06 \\
0.303\end{array}$ \\
\hline & 20 & $\begin{array}{c}0.26 \\
(0.22)\end{array}$ & $\begin{array}{l}1.61^{* * *} \\
(0.45)\end{array}$ & $\begin{array}{c}0.33^{*} \\
(0.17)\end{array}$ & 0.49 & $\begin{array}{l}7.30 \\
0.026\end{array}$ \\
\hline \multirow[t]{2}{*}{$\begin{array}{l}\text { Sweden } \\
\text { 1994:Q1-2003:Q2 }\end{array}$} & 38 & $\begin{array}{c}0.27 \\
(0.22)\end{array}$ & $\begin{array}{l}0.47^{* *} \\
(0.24)\end{array}$ & - & 0.09 & $\begin{array}{c}13.00 \\
0.002\end{array}$ \\
\hline & 38 & $\begin{array}{l}0.37^{* *} \\
(0.16)\end{array}$ & $\begin{array}{l}0.51^{* * *} \\
(0.16)\end{array}$ & $\begin{array}{l}0.69^{* * *} \\
(0.11)\end{array}$ & 0.56 & $\begin{array}{c}10.00 \\
0.007\end{array}$ \\
\hline \multirow[t]{2}{*}{$\begin{array}{l}\text { United Kingdom } \\
\text { 1997:Q4-2003:Q2 }\end{array}$} & 23 & $\begin{array}{c}0.39 \\
(0.26)\end{array}$ & $\begin{array}{l}0.73^{* *} \\
(0.35)\end{array}$ & - & 0.11 & $\begin{array}{l}7.19 \\
0.027\end{array}$ \\
\hline & 22 & $\begin{array}{l}0.58^{* *} \\
(0.24)\end{array}$ & $\begin{array}{c}0.52 \\
(0.32)\end{array}$ & $\begin{array}{l}0.47^{* *} \\
(0.19)\end{array}$ & 0.32 & $\begin{array}{l}2.22 \\
0.330\end{array}$ \\
\hline \multirow[t]{2}{*}{$\begin{array}{l}\text { United States } \\
\text { 1987:Q1-1996:Q4 }\end{array}$} & 37 & $\begin{array}{c}0.02 \\
(0.21)\end{array}$ & $\begin{array}{c}0.55^{*} \\
(0.31)\end{array}$ & - & 0.03 & $\begin{array}{c}13.57 \\
0.001\end{array}$ \\
\hline & 37 & $\begin{array}{c}0.02 \\
(0.19)\end{array}$ & $\begin{array}{c}0.46 \\
(0.27)\end{array}$ & $\begin{array}{l}0.43^{* * *} \\
(0.14)\end{array}$ & 0.23 & $\begin{array}{l}7.20 \\
0.027\end{array}$ \\
\hline
\end{tabular}

NOTE: ${ }^{* * *} / * * *$ Indicate significance at the $1 / 5 / 10$ percent levels, respectively. Estimation is by ordinary least squares. Numbers in parentheses are standard errors. The "news" regressors are the central banks' four-quarter-ahead forecast revisions: e.g., the time- $t$ forecast of four-quarter GDP growth four quarters ahead, minus the time- $t-1$ forecast of four-quarter GDP growth five quarters ahead. See also notes to Tables 1 and 2.

having output and inflation forecast revisions comparable to those of Sweden.

The regression results appear in Table 4, with and without the lagged interest rate. As in the conventional forward-looking reaction function estimates above, the horizon $k$ is set to four quarters. This specification works very well for New Zealand, with a highly significant response to inflation news and a positive (but not quite significant) response to GDP news. In addition, the specification eliminates the serial correlation in the residuals, with an LM test statistic for second-order serial correlation of only 1.06. (The lagged interest rate revision is only marginally significant when it is included, although the residuals appear more highly serially correlated in this case.) The specification also works well for Sweden, with a significant, positive response to both output and inflation news; unlike New Zealand, the coefficient on the lagged interest rate term remains quite large, even in this specification. Moving to the "reaction to news" specification greatly improves the U.K. estimates: the coefficients on output and inflation news have the right sign, the magnitudes are plausible, and (depending on the specification) the responses are statistically significant. The coefficient on the lagged interest rate is much smaller (less than 0.5, rather than above 1.0), and there is no evidence of serial correlation in the residuals. The specification works least well for the United States, where only the inflation coefficient is even marginally significant and the United States $R^{2}$ is low. One successful aspect of the "reaction to news" specification is the large reduction in the coefficient on the lagged interest rate for the Bank of England, the RBNZ, and the Fed. This result supports Rudebusch's (2002) contention that at least some of the serial correlation in conventionally specified instrument rules represents a response to an omitted variable, rather than interest rate smoothing per se. Indeed, for the United States the estimated lag coefficient of 0.43 is very close to the 0.4 Rudebusch obtains from term structure estimates of funds rate 
predictability, and it implies a much more plausible level of interest rate smoothing. It is also not far from the smoothing coefficient of 0.54 reported by English, Nelson, and Sack (2002) for the forwardlooking specification with real-time data. The Riksbank is an exception in this regard: The estimated lag coefficient remains a highly significant 0.7 even in the "reaction to news" specification, perhaps suggesting a larger role for interest rate smoothing in that case. ${ }^{32}$

Another attractive feature of this specification is that it allows us to get a much clearer picture of the degree of "judgment" in the setting of policy, relative to a simple instrument rule. An assessment of the role of judgment was difficult to make in the conventional specifications, because it was hard to distinguish between the omitted, serially correlated $Z$ and interest rate smoothing. By contrast, the residual from equation (10) or (11) has a clearer interpretation in terms of revisions to the relevant judgment factors.

The interpretation is particularly clean in the case of New Zealand, where the non-constant interest rate assumption and the availability of data on $i_{t, t-1}$ mean the results are not muddled by the implausibility of the constant interest rate assumption. In this case, the respectable but still relatively low $R^{2}$ ( 0.39 without the lagged interest rate, 0.49 with the lagged rate) means no more than one-half of the variance in the interest rate can be traced directly to revisions in the output and inflation forecasts. Thus, even the (arguably) most rule oriented of all the IT central banks apparently still exercises a great deal of judgment in setting policy.

\section{What About Optimal Targeting Rules?}

An alternative way to describe central banks' behavior is in terms of a targeting rule, as opposed to the instrument rules considered in the preceding section. As stressed by Svensson (2003), this formulation has the advantage of being immune to the inclusion of judgment terms in the central bank's forecast, and in the size of the policy action needed to attain its target. While setting policy to achieve an inflation target at a given horizon might be considered one form of an ad hoc targeting rule, the question taken up in this section is whether inflation targeters' behavior can be characterized in terms of simple optimal targeting rules.

\footnotetext{
32 The estimate of $\rho$ shrinks if the sample is started in 1997 , however, suggesting that some of the apparent "smoothing" may be associated with the dramatic decline in interest rates in 1996.
}

With a backward-looking inflation process in which the inflation rate at time $t+1$ depends on the current output gap, $x_{t}$, the specific targeting rule can be written as

$$
\pi_{t+\tau, t}-\pi^{*}=\left(\lambda / \alpha_{x}\right)\left(x_{t+\tau, t}-x_{t+\tau-1, t}\right),
$$

i.e., as a linear relationship between the forecast inflation gap in period $t+\tau$ and the forecast change in the output gap between periods $t+\tau-1$ and $t+\tau .33$ (Note that here, the period corresponds to the length of time it takes for a change in the output gap to affect inflation, rather than a calendar quarter.) The constant of proportionality is the ratio of $\lambda$, the weight on output in the loss function, to $\alpha_{x}$, which is effectively the slope of the aggregate supply relation (i.e., $\partial \pi_{t+1} / \partial \pi_{t}$ ).

The intuition behind this condition is straightforward and can be put in terms of marginal costs and benefits. Take the case of $\tau=2$,

$$
\pi_{t+2, t}-\pi^{*}=\left(\lambda / \alpha_{x}\right)\left(x_{t+2, t}-x_{t+1, t}\right),
$$

for example. Suppose inflation in period $t+2$ were forecast to come in above its target, $\pi^{*}$. With a quadratic loss function, the marginal benefit of reducing inflation is simply equal to the gap between inflation and its target. With a backward-looking inflation process and a one-period lag in the response of inflation, reducing inflation in period $t+2$ requires running a negative output gap at time $t+1$, relative to the future gap. In terms of output, the cost of reducing inflation is proportional to $1 / \alpha_{x}$; this increases the loss function by an amount $\lambda / \alpha_{x}$. At the optimum, the marginal benefit in terms of inflation reduction is equated to the marginal cost of foregone output. 34

The bottom line is that under the assumption of a backward-looking inflation process, optimal monetary policy should induce a positive correlation between the forecast inflation gap and the forecast change in the output gap. This is not true if the inflation process is assumed to be forward-looking, however. In this case, the relevant targeting rule is

$$
\pi_{t+\tau, t}-\pi^{*}=-\left(\lambda / \alpha_{x}\right)\left(x_{t+\tau, t}-x_{t+\tau-1, t}\right),
$$

and optimal policy induces a negative correlation

\footnotetext{
33 See Svensson (2003, equation 5.13). Note that this reflects the approximation that the discount factor, $\delta$, is close to unity.

34 This explanation is admittedly somewhat heuristic. See Svensson (2003) for a more precise (but arguably less intuitive) explanation in terms of the relevant marginal rates of substitution and transformation.
} 
between the forecast inflation gap and the forecast change in the output gap.

Indeed, the only difference between this rule and the one for the backward-looking inflation process is the negative sign multiplying the change in the output gap. Although it may seem odd that a simple alteration to the assumed behavior of inflation should change the sign of the relationship describing optimal monetary policy, the intuition is straightforward. In the forward-looking inflation model, inflation in period $t+2$ responds contemporaneously to the period- $t$ expectation of the output gap in period $t+2$. Thus, faced with greater-than-desired inflation in period $t+2$, policy will tighten, inducing a negative output gap (relative to the previous period) in that period in order to bring inflation down.

This particular specific targeting rule corresponds to one derived under pre-commitment, or a "timeless" perspective. Under discretion, the targeting rule would look like

$$
\pi_{t+\tau, t}-\pi^{*}=-\left(\lambda / \alpha_{x}\right) x_{t+\tau, t},
$$

and not exhibit the "history dependence" that is a hallmark of the pre-commitment solution. In this case, optimal policy induces a negative correlation between the forecast inflation gap and the forecast output gap itself, rather than its change.

The lack of a clear implication for even the sign of the relationship between inflation and output gap forecasts means it is hard to put any of these targeting rules to the test empirically-after all, either a positive or a negative correlation could be interpreted as evidence that the central bank was obeying a specific targeting rule of some sort. By contrast, the signs of the coefficients in the optimal instrument rules do not depend on the assumed nature of the inflation process, although the magnitudes do depend on this assumption. In any case, any Phillips curve fit to the data would likely contain both forward- and backward-looking terms, undoubtedly making the relevant instrument rules more involved than those summarized above.

Further complicating matters is the question of where to put the error term in a regression used to estimate relationships like (12), (14), or (15) and what that error term actually means. After all, these targeting rules should hold exactly in terms of the central banks' forecasts, assuming those forecasts embody the assumption that policy behaves optimally; any judgment should already be incorporated into the central banks' forecasts. (In the context of estimating an instrument rule, the vice of judgment terms becomes a virtue, in that it at least suggests a plausible rationale for an error term in the regression.) One potential source of error is mismeasurement of the forecast output gap, which, as described above, can generally only be inferred (imperfectly) from central banks' published GDP forecasts. Another potential source is that central banks behave suboptimally - although in this case it is not clear whether the error term from any less-than-optimal policy should be thought of as orthogonal to the inflation or the output gap forecasts (if either).

Our crude but effective solution to this normalization problem is to report the correlation coefficients, rather than the estimated slope coefficients from regressions. The benefit of this approach is that the correlation coefficient does not depend on the normalization; the cost, of course, is that it says nothing directly about the size of the parameter of interest, $\lambda / \alpha_{x}$. But at least the correlation can say something about the "closeness" of the empirical relationship implied by the targeting rule; and, given that even the sign of the relationship is up for grabs, this seems like a reasonable compromise.

Table 5 reports the correlations relevant to the three targeting rules discussed above. The first two are those between the forecast inflation gap and the forecast change in the output gap pertaining to the backward-looking inflation process and the forwardlooking inflation process under pre-commitment, for the four- and eight-quarter-ahead horizons. Also reported are those between the forecast inflation and output gaps pertaining to the forward-looking, discretionary case.

In a few cases, there is a significant, negative relationship between forecasts of the inflation gap and forecasts of the change in the output gap, consistent with optimal monetary policy with a forwardlooking inflation process. For New Zealand, there is a correlation of -0.46 at the four- to eight-quarter horizon; for the United Kingdom, a negative correlation of a similar magnitude is observed at the shorter zero- to four-quarter horizon. The correlations are relatively weak and insignificant in the case of Sweden.

The correlation is a surprisingly strong -0.69 for the United States at the four- to eight-quarter horizon. Interestingly, this is almost entirely the result of the early 1990s' disinflation, when the Green Book contained forecasts for above-average (but falling) inflation along with a widening output gap-a period typically thought of more in terms of serendipitous "opportunistic disinflation" than as 


\section{Table 5}

\section{Output-Inflation Correlations Corresponding to Targeting Rules}

\begin{tabular}{lccc} 
& \multicolumn{2}{c}{ Correlations between } \\
\cline { 2 - 4 } & \multicolumn{2}{c}{$\left(\pi_{t+k, t}-\pi^{*}\right),\left(x_{t+k, t}-x_{t+k-4, t}\right)$} & $\left(\pi_{t+k, t}-\pi^{*}\right),\left(x_{t+k, t}\right)$ \\
\cline { 2 - 4 } & $k=4$ & -0.455 & $k=4$ \\
\hline New Zealand & -0.054 & $(0.03)$ & 0.415 \\
1997:Q4-2003:Q2 & $(0.81)$ & -0.144 & $(0.04)$ \\
Sweden & -0.181 & $(0.42)$ & 0.082 \\
1994:Q1-2003:Q2 & $(0.27)$ & 0.303 & $(0.62)$ \\
United Kingdom & -0.419 & $(0.16)$ & 0.325 \\
1997:Q4-2003:Q2 & $(0.05)$ & -0.689 & $(0.12)$ \\
United States & -0.383 & $(0.00)$ & -0.263 \\
1987:Q1-1996:Q4 & $(0.02)$ & & $(0.21)$
\end{tabular}

NOTE: Numbers in parentheses are $p$ values for the hypothesis that the correlation is zero, assuming $\hat{\rho}(N-2)^{1 / 2} /\left(1-\hat{\rho}^{2}\right)^{1 / 2}$ follows a $t$ distribution with $N-2$ degrees of freedom, where $N$ is the number of observations. Because the output gap estimates often rely on the assumption that the eight-quarter-ahead gap is zero, the correlation between the inflation and output gap at this horizon is not reported.

an expression of forward-looking optimal monetary policy. In interpreting this result, it is important to keep in mind that the correlation is calculated assuming a constant mean, which implies an unchanged inflation target. Consequently, the negative correlation may reflect the downward shift in the Fed's inflation target that coincided with the 1991-92 recession.

The results are less supportive of the forwardlooking, discretionary specification involving the level of the output gap forecasts. The correlation is insignificant for the United Kingdom, Sweden, and the United States. Only for New Zealand is the correlation significant, but in this case it has the "wrong" (i.e., positive) sign.

Overall, the results of this exercise lend lukewarm support for describing inflation targeters' (and the Federal Reserve's) monetary policy in terms of a simple targeting rule, with an underlying forward-looking view of the inflation process. Still, with estimated correlation coefficients generally in the -0.3 to -0.5 range (corresponding to values for the $R^{2}, 0.09$ to 0.25 ), the goodness of fit is mediocre at best and somewhat worse than that of typical estimated instrument rules. It is also important to bear in mind that uncovering a negative correlation between inflation and output forecasts does not necessarily imply that policymakers were behaving optimally. Such a correlation could conceivably arise even with policy governed by a suboptimal or ad hoc rule (or none at all). Furthermore, the simple targeting rules considered here will be misspecified if the underlying inflation process contains both backward- and forward-looking elements. Extending the exercise to more realistic models, along the lines of Giannoni and Woodford (2003c), is clearly worthwhile-although it is also worth noting that, as the targeting rule becomes more complex, it becomes less useful as a means of communicating the policy trade-offs to the public.

\section{CONCLUSIONS}

The overall goal of this paper has been to bridge the gap between the literature describing the practice of IT and the literature on monetary policy rules. In an effort to dispel some of the terminological confusion that has contributed to this gap, section 2 reviewed some of the alternative definitions of the term "policy rule," while section 3 proposed various ways of interpreting IT within the context of these rules.

Ultimately, the question of how IT shapes monetary policy is an empirical one, however. And here, the empirical results of section 4 suggest a number of important conclusions. The first is that simple instrument rules do provide a reasonable approximation to the conduct of monetary policy, both by inflation targeters and by the Federal Reserve. Second, instrument rules based on forecasts of inflation and output perform better than those based 
only on current output and inflation. Third, while inflation targeters tend to exhibit a somewhat larger response to inflation forecasts than the Federal Reserve, inflation targeters are not "inflation nutters." Although the results depend somewhat on the specification used, forecasts of the output gap or GDP growth do seem to influence interest rate decisions, even controlling for the inflation outlook.

But these conventional instrument rules also leave a great deal unexplained (or at least "explained" only by the lagged interest rate). This observation suggests a fourth conclusion, namely, that central banks exercise a great deal of judgment or discretion relative to these rules. Estimates of an instrument rule from a novel "reaction to news" specification indicate that the Reserve Bank of New Zealand probably comes closest to a pure inflation forecast targeter; but even then, less than half of the variance from the planned interest rate path can be traced to forecast revisions.

A fifth conclusion is that simple optimal targeting rules of the kind advocated by Svensson (2003) do not provide a particularly good description of the conduct of monetary policy for any of the central banks considered. Fitting optimal targeting rules to the data, however, is complicated by the fact that central banks generally do not report output gaps, much less forecasts of those gaps; moreover, theory alone provides no clear guide as to the correct sign of the correlation implied by targeting rules.

At the level of estimated targeting or instrument rules, it is hard to draw sharp distinctions between the behavior of the three bona fide inflation targeters studied and that of the Federal Reserve. But, in general, the connection between changes in the short-term interest rate and forecast revisions is looser for the Fed than for the full-fledged inflation targeters. A sixth conclusion that could be drawn from the results, therefore, is that the FOMC uses even more judgment than the (significant) amount exercised by the inflation targeters.

While they may disappoint those who view IT purely in terms of a policy rule, these conclusions will come as no surprise to those familiar with the practice of IT, as described, for example, by Heikensten and Vredin (2002). At the same time, the lack of a sharp, qualitative difference between the Fed's behavior and that of the inflation targeters will probably do little to alter the priors of skeptics, such as Ball and Sheridan (2003), who contend the policy makes little practical difference. 35

\footnotetext{
${ }^{35}$ See, for example, the discussion in Posen (2002).
}

A hypothesis left unexplored in this paper is that the real impact of IT is not so much on central bank policymaking, per se, as it is on the impact of those policy decisions upon inflation expectations in the markets and the broader public; that is, that talk does matter after all. This interpretation of IT suggests that the response of expectations to economic news, or to policy itself, should be more "anchored" for inflation targeters than for lesstransparent non-inflation targeters, as suggested in Kuttner and Posen $(1999,2001)$ and Levin, Natalucci, and Piger (2004). If so, then a better place to look for effects of IT would be in the financial markets, and particularly in the prices of assets that embody inflation expectations. Examining financial markets' response to policy - and, in particular, to "discretionary" policy actions with no apparent connection to the central banks' forecasts - may prove informative as to whether IT can anchor expectations as its proponents claim.

\section{REFERENCES}

Agénor, Pierre-Richard and Masson, Paul R. "Credibility, Reputation, and the Mexican Peso Crisis." Journal of Money, Credit, and Banking, February 1999, 31(1), pp. 70-84.

Archer, David. "Are the Policy Rules Proposed in the Literature Good Enough for Practical Use?” Paper prepared for the Norges Bank workshop, "The Role of Monetary Policy in Inflation Targeting Regimes: Theory Meets Practice.” Oslo, May 5-6, 2003.

Ball, Laurence and Sheridan, Niamh. "Does Inflation Targeting Matter?” NBER Working Paper No. 9577, National Bureau of Economic Research, 2003.

Batini, Nicoletta and Haldane, Andrew G. "ForwardLooking Rules for Monetary Policy,” in J.B. Taylor, ed., Monetary Policy Rules. Chicago: University of Chicago Press, 1999, pp. 157-92.

Berg, Claes; Jansson, Per and Vredin, Anders. "How Useful Are Simple Rules for Monetary Policy? The Swedish Experience." Unpublished manuscript, Sveriges Riksbank, 2002.

Bernanke, Ben S.; Laubach, Thomas; Mishkin, Frederic S. and Posen, Adam S. Inflation Targeting: Lessons from the International Experience. Princeton, NJ: Princeton University Press, 1999.

Bofinger, Peter. "Inflation Targeting: Much Ado About Nothing (New)." Paper prepared for the annual meeting 
of the Ausschuss für Geldtheorie und Geldpolitik des Vereins für Socialpolitik. Frankfurt, Germany, February 25, 2000 .

Boivin, Jean. "Has U.S. Monetary Policy Changed? Evidence from Drifting Coefficients and Real-Time Data." Unpublished manuscript, Columbia University, 2003.

Carare, Alina and Stone, Mark. "Inflation Targeting Regimes," IMF Working Paper No. 03/9, International Monetary Fund, 2003.

Clarida, Richard; Galí, Jordi and Gertler, Mark. "The Science of Monetary Policy: A New Keynesian Perspective." Journal of Economic Literature, December 1999, 37(4), pp. 1661-707.

Clarida, Richard; Galí, Jordi and Gertler, Mark. "Monetary Policy Rules and Macroeconomic Stability: Evidence and Some Theory." Quarterly Journal of Economics, February 2000, 115(1), pp.148-80.

Debelle, Guy. "The Australian Approach to Inflation Targeting." Unpublished manuscript, Massachusetts Institute of Technology, 2003.

Drazen, Allan and Masson, Paul R. "Credibility of Policies versus Credibility of Policymakers." Quarterly Journal of Economics, August 1994, 109(3), pp. 735-54.

Drew, Aaron and Plantier, L. Christopher. "Interest Rate Smoothing in New Zealand and Other Dollar Bloc Countries." Discussion Paper 2000/10, Reserve Bank of New Zealand, 2000.

Eggertsson, Gauti B. and Woodford, Michael. "The Zero Bound on Interest Rates and Optimal Monetary Policy." Brookings Papers on Economic Activity, 2003, (1), pp. 139-211.

English, William B.; Nelson, William R. and Sack, Brian P. "Interpreting the Significance of the Lagged Interest Rate in Estimated Monetary Policy Rules." Finance and Economic Discussion Series No. 2002-24, Board of Governors of the Federal Reserve System, 2002.

Faust, Jon and Svensson, Lars E.O. "Transparency and Credibility: Monetary Policy with Unobservable Goals." International Economic Review, May 2001, 42(2), pp. 369-97.

Fracasso, Andrea; Genberg, Hans and Wyplosz, Charles. How Do Central Banks Write? An Evaluation of Inflation
Targeting by Inflation Targeting Central Banks. Geneva Reports on the World Economy, Special Report 2. London: Centre for Economic Policy Research, 2003.

Friedman, Benjamin M. and Kuttner, Kenneth N. "A Price Target for Monetary Policy? Lessons from the Experience with Money Growth Targets." Brookings Papers on Economic Activity, 1996, (1), pp. 77-125.

Friedman, Milton. Essays in Positive Economics. Chicago: University of Chicago Press, 1953.

Galí, Jordi. "Targeting Inflation in an Economy with Staggered Price Setting," in N. Loayza and R. Soto, eds., Inflation Targeting: Design, Performance, Challenges. Santiago, Chile: Central Bank of Chile, 2002.

Gavin, William T. "Inflation Targeting: Why It Works and How To Make It Work Better?" Business Economics, April 2004, 39(2), pp. 30-37.

Geraats, Petra. "Central Bank Transparency." Economic Journal, November 2002, 112(483), pp. 532-65.

Giannoni, Marc P. and Woodford, Michael. "Optimal Interest Rate Rules: I. General Theory.” NBER Working Paper No. 9419, National Bureau of Economic Research, 2003a.

Giannoni, Marc P. and Woodford, Michael. "Optimal Interest Rate Rules: II. Applications.” NBER Working Paper No. 9420, National Bureau of Economic Research, 2003b.

Giannoni, Marc P. and Woodford, Michael. "Optimal Inflation Targeting Rules.” NBER Working Paper No. 9939, National Bureau of Economic Research, 2003c.

Goldfeld, Stephen. Comment on S. De Vay, "Modeling the Banking Firm: A Survey." Journal of Money, Credit, and Banking, November 1984, 16(4), pp. 609-11.

Greenspan, Alan. Statement before the Subcommittee on Domestic Monetary Policy Committee on Banking, Finance and Urban Affairs, U.S. House of Representatives, July 28, 1988.

Hall, Robert. "Stochastic Implications of the Life Cycle Permanent Income Hypothesis.” Journal of Political Economy, December 1978, 86(6), pp. 971-87.

Heikensten, Lars and Vredin, Anders. "The Art of Inflation Targeting.” Sveriges Riksbank Economic Review, 2002, (4), pp. 5-34. 
Herrendorf, Berthold. "Inflation Targeting as a Way of Precommitment." Oxford Economic Papers, July 1998, 50(3), pp. 431-48.

Huang, Angela; Margaritis, Dimitri and Mayes, David. "Monetary Policy Rules in Practice: Evidence from New Zealand." Discussion Paper No. 18/2001, Bank of Finland, 2001.

Jansson, Per and Vredin, Anders. "Forecast-Based Monetary Policy: The Case of Sweden.” International Finance, Winter 2003, 6(3), pp. 349-82.

King, Mervyn. "Changes in UK Monetary Policy: Rules and Discretion in Practice." Journal of Monetary Economics, June 1997, 39(1), pp. 81-97.

Kuttner, Kenneth N. and Posen, Adam S. "Does Talk Matter After All? Inflation Targeting and Central Bank Behavior." Federal Reserve Bank of New York Staff Report No. 88, 1999.

Kuttner, Kenneth N. and Posen, Adam S. "Inflation, Monetary Transparency, and G3 Exchange Rate Volatility," in M. Balling, E.H. Hochreiter, and E. Hennessy, eds, Adapting to Financial Globalisation: International Studies in Monetary Banking. Volume 14. London: Routledge, 2001, pp. 229-58.

Leitemo, Kai."Targeting Inflation by Constant-Interest-Rate Forecasts." Journal of Money, Credit, and Banking, August 2003, 35(4), pp. 609-26.

Leeper, Eric M. “An Inflation Reports Report.” Sveriges Riksbank Economic Review, 2003, (3), pp. 94-118.

Levin, Andrew; Natalucci, Fabio and Jeremy, Piger. "The Macroeconomic Effects of Inflation Targeting." Federal Reserve Bank of St. Louis Review, July/August 2004 , 86(4), pp. 51-80.

McCallum, Bennett. "Inflation Targeting and the Liquidity Trap," in N. Loayza and R. Soto, eds., Inflation Targeting: Design, Performance, Challenges. Santiago, Chile: Central Bank of Chile, 2002.

McCaw, Sharon and Ranchhod, Satish. "The Reserve Bank's Forecasting Performance.” Reserve Bank of New Zealand Bulletin, December 2002, 65(4), pp. 5-23.

McNees, Stephen K. "Modeling the Fed: A Forward-Looking Monetary Policy Reaction Function." New England Economic Review, November/December 1986, pp. 3-8.
McNees, Stephen K. "A Forward-Looking Monetary Policy Reaction Function: Continuity and Change." New England Economic Review, November/December 1992, pp. 3-13.

Mishkin, Frederic and Schmidt-Hebbel, Klaus. "A Decade of Inflation Targeting in the World: What Do We Know and What Do We Need To Know?" in N. Loayza and R. Soto, eds., Inflation Targeting: Design, Performance, Challenges. Santiago, Chile: Central Bank of Chile, 2002.

Nikolov, Kalin. "Monetary Policy Rules at the Bank of England.” Paper prepared for the European Central Bank workshop, "The Role of Policy Rules in the Conduct of Monetary Policy.” Frankfurt, Germany, March 11-12, 2002.

Orphanides, Athanasios. "Monetary Policy Rules Based on Real-Time Data." American Economic Review, September 2001, 91(4), pp. 964-85.

Pagan, Adrian. "Report on Modelling and Forecasting at the Bank of England," 2003; www.bankofengland.co.ul/ pressrelease/2003/paganreport.pdf.

Posen, Adam S. Commentary on G. Chortareas, D. Stasavage, and G. Sterne, "Does It Pay To Be Transparent? International Evidence from Central Bank Forecasts." Federal Reserve Bank of Saint Louis Review, July/August 2002, 84(4) pp. 119-26.

Reifschneider, David L.; Stockton, David J. and Wilcox, David. "Econometric Models and the Monetary Policy Process." Carnegie-Rochester Conference Series on Public Policy, December 1997, 47, pp. 1-37.

Rogoff, Kenneth. "The Optimal Degree of Commitment to an Intermediate Monetary Target." Quarterly Journal of Economics, November 1985, 100(4), pp. 1169-89.

Romer, Christina D. and Romer, David H. "Federal Reserve Information and the Behavior of Interest Rates." American Economic Review, June 2000, 90(3), pp. 429-57.

Rudebusch, Glenn and Svensson, Lars E.O. "Policy Rules for Inflation Targeting," in J.B. Taylor, ed., Monetary Policy Rules. Chicago: University of Chicago Press, 1999, pp. 203-46.

Rudebusch, Glenn. "Term Structure Evidence on Interest Rate Smoothing and Monetary Policy Inertia." Journal of Monetary Economics, September 2002, 49(6), pp. 1161-87.

Simons, Henry. "Rules versus Authorities in Monetary 
Policy." Journal of Political Economy, February 1936, 44(1), pp. 1-30.

Sterne, Gabriel. "Inflation Targets in a Global Context," in N. Loayza and R. Soto, eds., Inflation Targeting: Design, Performance, Challenges. Santiago, Chile: Central Bank of Chile, 2002.

Stone, Mark R. "Inflation Targeting Lite.” IMF Working Paper No. 03/12, International Monetary Fund, 2003.

Svensson, Lars E.O. "Inflation Targeting as a Monetary Policy Rule.” Journal of Monetary Economics, June 1999 , 43(3), pp. 607-54.

Svensson, Lars E.O. “The First Year of the Eurosystem: Inflation Targeting or Not?" American Economic Review, May 2000, 90(2), pp. 95-99.

Svensson, Lars E.O. "What Is Wrong with Taylor Rules? Using Judgment in Monetary Policy Through Targeting Rules." Journal of Economic Literature, June 2003, 41(2), pp. $426-77$.

Taylor, John B. "Discretion versus Policy Rules in Practice.”
Carnegie-Rochester Conference Series on Public Policy, December 1993, 39, pp. 195-214.

Taylor, John B. "Recent Developments in the Use of Monetary Policy Rules," in C. Joseph and A.H. Gunawan, eds., Monetary Policy and Inflation Targeting in Emerging Economies. Jakarta: Bank Indonesia, 2000.

Truman, Edwin M. Inflation Targeting in the World Economy. Washington, DC: Institute for International Economics, 2003.

Vredin, Anders. Discussion of S. Honkapohja and K. Mitra "Problems in Inflation Targeting Based on Constant Interest Rate Projections.” Prepared for the conference, "Expectations, Learning and Monetary Policy." Eltville, Germany, August 30-31, 2003.

Willams, John C. "Simple Rules for Monetary Policy." Federal Reserve Bank of San Francisco Economic Review, 2003, pp. 1-12.

Woodford, Michael. Interest and Prices: Foundations of a Theory of Monetary Policy. Princeton, NJ: Princeton University Press, 2003.

Appendix

\section{CONSTRUCTING REAL-TIME OUTPUT GAP PROXIES}

As described in section 4, the method used to construct estimates of the output gap involves accumulating the difference between the forecast real GDP growth rates and some assumed potential growth rate, imposing a terminal condition on the output gap at the end of the forecast horizon. This recursive technique is adapted to the specifics of each central bank's forecasts, as described here.

\section{The United Kingdom}

The Bank of England consistently reports fourquarter real GDP and inflation forecasts at a horizon of one to eight quarters ahead. Because the individual quarterly GDP forecasts are not reported, it is not possible to back-out a quarterly output gap series. But the four-quarter growth figures can be used to construct measures of the current gap and the four - quarter-ahead forecasts. The recursion can be described as follows:

$$
\begin{aligned}
& x_{t+8}=0 \\
& x_{t+k}=x_{t+k+4}-\left(g-\Delta_{4} y_{t+k+4}\right) \text { for } k=4 \text { and } 0,
\end{aligned}
$$

where $x_{t+k}$ is the $k$-quarter-ahead output gap, $g$ is the growth rate of potential output (assumed to be a constant 2.4 percent per year), and $\Delta_{4} y_{t+k}$ is the forecast four-quarter real GDP growth rate (based on the reported mode of the forecast distribution).

\section{Sweden}

The Sveriges Riksbank consistently reports a current-year forecast for inflation and output and forecasts for the subsequent two "out" years. Because of this structure, the effective forecast horizon varies between 8 and 11 quarters. The terminal condition on the output gap is imposed only on the longest, the 11-quarter "benchmark" forecast. Letting $x_{s+k, q}$ represent the output gap in the qth quarter of year 
$s+k$, the gap for the first quarter of each year is constructed recursively in a manner similar to that of the Bank of England:

$$
\begin{aligned}
& x_{s+3,1}=0 \\
& x_{s+k, 1}=x_{s+k+1,1}-\left(g-\Delta y_{s+k}\right) \text { for } k=2 \text { to } 0,
\end{aligned}
$$

where $\Delta y_{s+k}$ is real GDP growth in year $s+k$. Subsequent quarters' output gap estimates are constructed by accumulating over the relevant forecast horizon the forecast revisions relative to the previous quarter. Potential growth was assumed to be 2.6 percent throughout, except in 2000 when it was 2.8 percent and 2002 and 2003, when values of 2.5 and 2.4 percent were used, respectively. The end-of-forecasthorizon gap was assumed to be zero, except in 1999, when the March Inflation Report referred to underutilized resources at the end of the forecast period and in 2000 when the March Inflation Report referred to capacity restrictions. For these years, the end-offorecast-period gaps are assumed to be -1 and 1 percent, respectively.

\section{New Zealand}

For 12 of the quarters in the sample, the Reserve Bank of New Zealand reports quarterly estimates of the output gap. For the remaining 12 quarters, estimates were constructed using a method similar to that used for the United Kingdom, based on reported four-quarter real GDP growth rate forecasts.

\section{The United States}

The Federal Reserve is unique in that the Green Book reports forecasts for quarterly GNP and/or GDP growth, which allows the quarterly implied path of the output gap to be extracted. However the forecast horizon varies between four and nine quarters, depending on the date at which the forecast was made. As in Sweden, the terminal condition on the output gap is imposed only for the long-horizon (eight- or nine-quarter-ahead) "benchmark" forecasts, and the estimated gap is constructed as

$$
\begin{aligned}
& x_{t+T}=0 \\
& x_{t+k}=x_{t+k+1}-\left(g-\Delta y_{t+k}\right) \text { for } k=T-1 \text { to } 0 .
\end{aligned}
$$

The accumulated revisions in the quarterly GDP growth forecasts are used to update the gap estimates between "benchmarks." Forecast data for the first through fourth quarters are taken from the Green Books dated January or February, May, August, and October or November. Prior to January 1992, output growth is based on real GNP; after this, real GDP is used. 
RE V I E W 